\title{
Barriers in Implementing E-Learning in Hormozgan University of Medical Sciences
}

\author{
Parvin Lakbala ${ }^{1,2}$ \\ ${ }^{1}$ Health Information Management Research Center, Hormozgan University of Medical Sciences, Bandar Abbas, \\ Iran \\ ${ }^{2}$ Department of Health Information Technology, Faculty of Para-Medicine, Hormozgan University of Medical \\ Sciences, Bandar Abbas, Iran \\ Correspondence: Parvin Lakbala, Health Information Management Research Center, Hormozgan University of \\ Medical Sciences, Bandar Abbas, Iran. Tel: 98-763-366-6365. E-mail: Parvin_lakbala@yahoo.com
}

Received: September 29, 2015 Accepted: October 26, 2015 Online Published: November 3, 2015

doi:10.5539/gjhs.v8n7p83 URL: http://dx.doi.org/10.5539/gjhs.v8n7p83

\begin{abstract}
Background: E-learning provides an alternative way for higher educational institutes to deliver knowledge to learners at a distance, rather than the traditional way. The aim of this study is to identify the barrier factors of e-learning programs in Hormozgan University of Medical Sciences (HUMS) in respect of the students and lecturers' point of view.
\end{abstract}

Methods: A cross-sectional study based on a questionnaire was conducted among 286 of students and lecturers in the nursing, midwifery and paramedic schools of HUMS. Two hundred and eighty-six participants filled in the questionnaire: 256 students, and 30 lecturers.

Results: Results of the study showed a lack of proper training in e-learning courses of the university 182 (69.1\%), limited communication with the instructor 174 (68\%) and the learners dominance of English language $174(68 \%)$ showed the greatest importance for the students. The awareness about e-learning program was $80 \%$ and $43 \%$ among lecturers and students respectively.

The dominance of English language 26 (86.7\%) and lack of research grants for e-learning $23(76.6 \%)$ and lack of proper training on e-learning courses from the university $20(66.7 \%)$ were the most important barrier factors of implementing e-learning for lecturers. E-learning courses to supplement classroom teaching was a solution that mentioned by the majority of students $240(93.8 \%)$ and lecturers $29(96.7 \%)$ in this study.

Conclusions: The positive perception of e-learning is an important consequence effect in the future, educational development of nursing, midwifery and paramedic schools.

Keywords: E-learning, technology, learning, distance

\section{Background}

The Internet is now widely used as a communication medium for personal, commercial and educational purposes. E-learning is rapidly becoming a key element of institutional teaching and learning strategies with many academic departments seizing the opportunity to use new technologies to enhance their educational provision. Commonly, universities support it through the provision of virtual learning environments which provide students with access to single and multi-media course materials, online collaboration and computer aided assessment.

Information and Communication Technology (ICT) has become a major focus of interest in the educational field. There are many benefits which speak for the integration of ICT in education, such as increasing the quality of learning (Chang, 2006), providing learners with technological skills and encouraging learners to be more interactive (Van-Braak, 2001), promoting teachers and students' performance and motivation, and removing the limitations of time and space in instructional processes (Al-zaidiyeen et al., 2008).

Functionally e-learning includes a wide variety of learning strategies and ICT applications for exchanging information and gaining knowledge. Such ICT applications include television and radio; Compact Discs (CDs) and Digital Versatile Discs (DVDs); video conferencing; mobile technologies; web-based technologies; and electronic learning platforms. This section discusses what these ICTs entail as well as their pedagogical, 
technical and cost implications (Sife, 2007).

The web conferencing technologies integrate presentation, collaboration and communication on one platform. Providing synchronous online learning space they offer possibility of emulation of traditional classrooms (Morningstar \& Primlani, 2006). The role of modern teacher has changed. He is now not only the source of knowledge, but also the activator of discussion and a stimulator of creativity and critical thinking (Hernandez et al., 2007).

While the value of e-learning lies in its ability to train anyone, anytime, anywhere, implementing and sustaining e-learning programs require more than merely moving education and learning online (Harris, 2002). Secondly, if we are to develop, deliver and administer e-learning programs, and train educators to become competent e-learning facilitators, a high level of investment in ICT infrastructure is required. Successful e-learning implementation therefore depends on building a strategy that meets the needs of the learners and the business goals of the institution. In Iran among 44 universities of medical sciences only 4 universities have managed to implement the e-learning platform (Mehralborz University, 2015). The aim of this study is to identify lecturers' and students' perceptions toward the importance of barriers factors and their attitudes toward various methods for implementing e-learning program in the Hormozgan University of Medical Sciences (HUMS).

\section{Methods}

A cross-sectional study based on a questionnaire was carried out with two different groups of subjects: students academic group (Nursing and Midwifery, Laboratory, Health information technology, Radiology, Anesthesia and Operation room technology) and lecturers of the paramedic, nursing and midwifery schools of HUMS, Bandar Abbas, Iran. For the academic year 2013-2014, the paramedic, nursing and midwifery schools of HUMS was constituted by approximately 1300 students and 46 lecturers. Stratified sampling method was used which included 346 respondents representing a variety of two different groups (lecturers and students).

Data were collected through two anonymous questionnaire instrument that distributed to 300 students of the paramedic, nursing and midwifery schools of HUMS students and 46 lectures during the fall semester of 2014 where 286 (83\%) were returned. Respondents for this study consisted of 256 students (166 females and 90 males) and 30 lectures ( 15 females and 15 males).

The questionnaire was designed especially for the purpose of this study. It was based on a literature review of previous studies regarding participants' perceptions toward the Importance of barriers factors and participants' attitudes toward various methods for implementing e-learning program.

We tested the questionnaire in a pilot study with a sample of 10 students and 2 lecturers who were not a part of the study population (Heath school students and lecturers at HUMS). A few changes in the wording of questions were made as a result of the pilot study.

The questionnaire was designed with 53 questions for lecturers and 43 questions for students. Questions were divided into several sections: Demographic questions, access to computers and the Internet; knowledge and perception of e-learning; participants' perceptions regarding the Importance of barriers factors and participants' attitudes toward various methods for implementing e-learning program. Various methods of questions were proposed: multiple choices and Likert scale type questions from 'very much' to 'very little' was used to determine participants' perceptions regarding the Importance of barrier factors and 'strongly agree' to 'strongly disagree' to determine participants' attitudes toward various methods for implementing e-learning program. Students' perceptions were evaluated based on a scale ranging from "very much" to "very little" in the Six categories of barrier factors (access-skill barriers, attitudinal barriers, cultural barriers, infrastructural barriers, barriers associated with integrating e-learning with traditional teaching and Disproportion between method and content) with 20 sub- categories. Lecturers perceptions were evaluated based on a scale ranging from "very much" to "very little" in Seven categories of barrier factors (access-skill barriers, attitudinal barriers, cultural barriers, infrastructural barriers, barriers associated with integrating e-learning and traditional teaching, disproportion between method and content credit \&encouraging barriers) and 24 sub- categories.

\subsection{Ethics}

This study was funded by the Deputy of Research and Technology of Hormozgan University of Medical Sciences, Iran (Grant No. 9381). The ethical review committee of Hormozgan University of Medical Sciences did not consider this study to require approval. Informed consent was obtained from participants.

\subsection{Data Analysis}

The collected data were analyzed using SPSS v. 12 (SPSS, Chicago, IL, USA) and $\chi^{2}$ test, with $\mathrm{P}<0.05$ 
considered statistically significant. The percentages and their $95 \%$ confidence intervals are presented.

\section{Results}

\subsection{Response rates}

Out of 346 questionnaires which distributed (300 for students and 46 for lecturers), 286 (83\%) questionnaires were completed and analyzed (256 from the students and 30 from the lecturers).

\subsection{Participant Profile}

All students were at the bachelor level. The group of lecturers came from 7 academic departments out of whom 56.9 had a long teaching experience (10 to over 20 years) (Table 1$)$.

Table 1. Participant profile

\begin{tabular}{|c|c|}
\hline Participant profile & No. $(\%)$ \\
\hline \multicolumn{2}{|l|}{ Gender } \\
\hline \multicolumn{2}{|l|}{ Lecturers: } \\
\hline Male & 50 \\
\hline Female & 50 \\
\hline \multicolumn{2}{|l|}{ Students } \\
\hline Male & 37 \\
\hline Female & 63 \\
\hline \multicolumn{2}{|l|}{ Age group } \\
\hline \multicolumn{2}{|l|}{ Lecturers: } \\
\hline$<30$ & 20 \\
\hline $30-39$ & 36.7 \\
\hline $40-49$ & 33.3 \\
\hline$>50$ & 10 \\
\hline \multicolumn{2}{|l|}{ Students: } \\
\hline $19-24$ years & 82 \\
\hline $25-29$ years & 9 \\
\hline$>30$ & 9 \\
\hline \multicolumn{2}{|l|}{ Lecturers educational level } \\
\hline Master degree & 83.3 \\
\hline Ph.D. & 16.7 \\
\hline \multicolumn{2}{|l|}{ Lecturers years work } \\
\hline$<10$ & 43.3 \\
\hline $10-20$ & 23.3 \\
\hline$>20$ & 33.4 \\
\hline \multicolumn{2}{|l|}{ Academic department (students): } \\
\hline Laboratory & 18.8 \\
\hline Health Information Technology & 11.9 \\
\hline Radiology & 9.8 \\
\hline Anesthesia & 14.1 \\
\hline Operating room & 16 \\
\hline Nursing & 13.7 \\
\hline Midwifery & 16 \\
\hline
\end{tabular}




\subsection{Knowledge About E-Learning and Computer}

Results showed that the use of computers and Internet among students and lecturers were between 1 to 8 hours per day. The awareness about e-learning program was $80 \%$ among lecturers, but $66.7 \%$ of them announced that they had not received an e-learning program in the past. Among lecturers, $40 \%$ of them were aware of the barrier factors for the implementation of distance education programs at the university. Among student group $21.5 \%$ of them had a private web and $26.6 \%$ had the experience in writing web. Awareness about e-learning program between student groups was $43 \%$ between student groups. Among students, $32.8 \%$ of them had received e-learning program in the past.

\subsection{E-Learning Barrier Factors}

Table 2 summarizes the students' perceptions regarding the importance of barrier factors to the implementation of e-learning in university. Pedagogical, technical and cost issues should be taken into account each specific technology while integrating ICTs in teaching and learning practices.

Lack of proper training in e-learning courses in the university $182(69.1 \%)$, limited communication with the instructor 174 (68\%) and the learners dominance of English language $174(68 \%)$ showed the greatest importance for the students (Table 2). Result showed negative attitudes towards new technologies 92 (35.9\%). Lack of comfort with technology, ranked the least important among students as the barrier factor for the implementation of e-learning programs. There are, indeed, significant associations between the field of study and lack of interest in e-learning program $\left(\chi^{2}=53.505, \mathrm{df}=28, \mathrm{P}<0.05\right)$ and not requiring knowledge of computer $(\chi 2=52.854$, $\mathrm{df}$ $=28, P<0.05$ ) with students' perceptions (table 2). Lack of guidance and information prior to enrollment in e-learning, perceived lack of support from faculty, and difficulties in contacting them mentioned in prior studies (Brown, 1996; Pierrakeas et al., 2004; Tresman, 2002). Other researchers have found that student characteristics such as computer literacy and confidence, reading ability, and time management skills played a role in successful course completion (Miller et al., 2003, Osbon, 2001; Rovai, 2003). Student skills in their comprehension of the English language and lack of knowledge of the software are important factors in successful implementation of e-learning course.

Table 2. Students' perceptions associated with the importance of barrier factors for the implementation of e-learning

\begin{tabular}{|c|c|c|c|c|c|}
\hline Students' Barrier factors & $\begin{array}{l}\text { Very much } \\
(\%)\end{array}$ & $\begin{array}{l}\text { Much } \\
(\%)\end{array}$ & $\begin{array}{l}\text { Moderate } \\
(\%)\end{array}$ & $\begin{array}{l}\text { Little } \\
(\%)\end{array}$ & $\begin{array}{l}\text { Very little } \\
(\%)\end{array}$ \\
\hline \multicolumn{6}{|l|}{ Access-Skill Barriers } \\
\hline Low access to computer & 94(36.7) & $68(26.6)$ & $58(22.7)$ & $28(10.9)$ & $8(3.1)$ \\
\hline Inadequate computer & $54(21.1)$ & $99(38.7)$ & $74(28.9)$ & $18(7.0)$ & $11(4.3)$ \\
\hline Little computer knowledge of students & $62(24.2)$ & $89(34.8)$ & $75(29.3)$ & $27(10.5)$ & $3(1.2)$ \\
\hline Limited communication with the instructor & $66(25.8)$ & $108(42.2)$ & $63(24.6)$ & $14(5.4)$ & $5(2.0)$ \\
\hline Poor communication & $45(17.6)$ & $97(37.9)$ & $86(33.6)$ & $20(7.8)$ & $8(3.1)$ \\
\hline \multicolumn{6}{|l|}{ Attitudinal barriers } \\
\hline \multirow{3}{*}{$\begin{array}{l}\text { Lack of interest in e-learning } \\
\text { No need for E-Learning } \\
\text { Negative attitudes towards new technologies }\end{array}$} & $40(15.6)$ & $77(30.1)$ & $85(33.2)$ & $37(14.5)$ & $17(6.6)$ \\
\hline & $39(15.2)$ & $77(30.1)$ & $76(29.7)$ & $43(16.6)$ & $21(8.2)$ \\
\hline & $38(14.8)$ & $54(21.1)$ & $74(28.9)$ & $57(22.3)$ & $33(12.9)$ \\
\hline \multicolumn{6}{|l|}{ Cultural Barriers } \\
\hline Lack of support & $54(21.1)$ & $92(35.9)$ & $67(26.2)$ & $25(9.8)$ & $18(7.0)$ \\
\hline Computer knowledge not require & $42(16.4)$ & $86(33.6)$ & $68(26.6)$ & $42(16.4)$ & $18(7.0)$ \\
\hline Lack of comfort with technology & $36(14.1)$ & $76(29.7)$ & $67(26.2)$ & $52(20.3)$ & $25(9.8)$ \\
\hline $\begin{array}{l}\text { Concerns about the ethical issues in the use of } \\
\text { Internet }\end{array}$ & $43(16.8)$ & $69(27.0)$ & $73(28.5)$ & $51(19.9)$ & $20(7.8)$ \\
\hline \multicolumn{6}{|l|}{ Infrastructure barriers } \\
\hline Limited infrastructure to support & $61(23.8)$ & $97(37.9)$ & $67(26.2)$ & $23(9.0)$ & $8(3.1)$ \\
\hline
\end{tabular}




\begin{tabular}{|c|c|c|c|c|c|}
\hline Lack of proper training in e-learning courses & $90(32.2)$ & $92(35.9)$ & $49(19.1)$ & $19(7.4)$ & $6(2.3)$ \\
\hline High cost of establishing & $57(22.3)$ & $81(31.6)$ & $85(33.2)$ & $25(9.8)$ & $8(3.1)$ \\
\hline \multicolumn{6}{|l|}{$\begin{array}{l}\text { Barriers associated with integrating } \\
\text { e-learning and traditional teaching }\end{array}$} \\
\hline $\begin{array}{l}\text { Complexity of integrating e-learning with } \\
\text { classroom instruction }\end{array}$ & $43(16.8)$ & $94(36.7)$ & $82(32.0)$ & $28(10.9)$ & $9(3.5)$ \\
\hline Learners mastery to English language & $74(28.9)$ & $100(39.1)$ & $59(23.0)$ & $19(7.4)$ & $4(1.6)$ \\
\hline \multicolumn{6}{|l|}{ Disproportion between method and content } \\
\hline $\begin{array}{l}\text { Disproportion of e-learning with curriculum } \\
\text { content }\end{array}$ & $45(17.6)$ & $105(41.0)$ & $74(28.9)$ & $24(9.4)$ & $8(3.1)$ \\
\hline $\begin{array}{l}\text { Disproportion of e-learning courses for the } \\
\text { academic mission }\end{array}$ & $35(13.7)$ & $99(38.7)$ & $80(31.2)$ & $33(12.9)$ & $9(3.5)$ \\
\hline $\begin{array}{l}\text { Concerns about the practical nature of some } \\
\text { courses are not offered electronically }\end{array}$ & $40(15.6)$ & $90(35.2)$ & $86(33.6)$ & $31(12.1)$ & $9(3.5)$ \\
\hline
\end{tabular}

Table 3 summarizes the lecturers' perceptions regarding the importance of barrier factors to the implementation of e-learning in university. Regarding the lecturers' perceptions in this survey, the dominance of English language $26(86.7 \%)$, lack of research grants for e-learning $23(76.6 \%)$ and lack of proper training on e-learning courses from the university $20(66.7 \%)$ were the most important barrier factors for the implementation of e-learning.

Lecturers noted that negative attitudes towards new technologies 7 (23.3\%) and lack of comfort with technology $11(36.7 \%)$ had the lowest degree of importance for the implementation of e-learning program. There are, indeed, significant associations between the lecturers, education level and complexity of integration of e-learning with classroom instruction $(\chi 2=10.975$, df $=4, P<0.05)$ and disproportion of e-learning with curriculum content knowledge of $(\chi 2=10.937, \mathrm{df}=4, P<0.05)$ and lectures perceptions (Table 3$)$.

Table 3. Lecturers' perceptions associated with the importance of barrier factors for the implementation of e-learning

\begin{tabular}{|c|c|c|c|c|c|}
\hline Lecturers' Barrier factors & $\begin{array}{l}\text { Very much } \\
(\%)\end{array}$ & $\begin{array}{c}\text { Much } \\
(\%)\end{array}$ & $\begin{array}{c}\text { Moderate } \\
\text { (\%) }\end{array}$ & $\begin{array}{l}\text { Little } \\
(\%)\end{array}$ & $\begin{array}{l}\text { Very little } \\
(\%)\end{array}$ \\
\hline \multicolumn{6}{|l|}{ Access-Skill Barriers } \\
\hline Low access to computer & $10(33.3)$ & $11(36.7)$ & $6(20.0)$ & $2(6.7)$ & $1(3.3)$ \\
\hline Inadequate computer & $5(16.7)$ & $12(40.0)$ & $6(20.0)$ & $6(20.0)$ & $1(3.3)$ \\
\hline Little computer knowledge of students & $5(16.7)$ & $9(30.3)$ & $11(36.7)$ & $2(6.7)$ & $3(10.0)$ \\
\hline Limited communication with the instructor & $5(16.7)$ & 11(36.7) & $13(43.3)$ & $1(3.3)$ & - \\
\hline Poor communication & $6(20.0)$ & 11(36.7) & $4(13.3)$ & $7(23.3)$ & $2(6.7)$ \\
\hline \multicolumn{6}{|l|}{ Attitudinal barriers } \\
\hline Lack of interest in e-learning & $3(10.0)$ & $11(36.7)$ & $8(26.7)$ & $7(23.3)$ & $1(3.3)$ \\
\hline No need for E-Learning & $6(20.0)$ & $10(33.3)$ & $7(23.3)$ & $5(16.7)$ & $2(6.7)$ \\
\hline Negative attitudes towards new technologies & $3(10.0)$ & $4(13.3)$ & $5(16.7)$ & $13(43.3)$ & $5(16.7)$ \\
\hline \multicolumn{6}{|l|}{ Cultural Barriers } \\
\hline Lack of support & $4(13.3)$ & $12(40.0)$ & $11(36.7)$ & $2(6.7)$ & $1(3.3)$ \\
\hline Computer knowledge not require & $4(13.3)$ & 11(36.7) & $9(30.0)$ & $5(16.7)$ & $1(3.3)$ \\
\hline Lack of comfort with technology & $3(10.0)$ & $8(26.7)$ & $9(30.0)$ & $9(30.0)$ & $1(3.3)$ \\
\hline Concerns about the ethical issues in the use of Internet & $4(13.3)$ & $9(30.3)$ & $8(26.7)$ & $7(23.3)$ & $2(6.7)$ \\
\hline
\end{tabular}




\begin{tabular}{|c|c|c|c|c|c|}
\hline \multicolumn{6}{|l|}{ Infrastructure barriers } \\
\hline Limited infrastructure to support & $8(26.7)$ & $14(46.7)$ & $8(26.7)$ & - & - \\
\hline Lack of proper training in e-learning courses & $6(20.0)$ & $14(46.7)$ & $8(26.7)$ & $2(6.7)$ & - \\
\hline High cost of establishing & $8(26.7)$ & $7(23.3)$ & $14(46.7)$ & $1(3.3)$ & - \\
\hline \multicolumn{6}{|l|}{$\begin{array}{l}\text { Barriers associated with integrating e-learning } \\
\text { and traditional teaching }\end{array}$} \\
\hline $\begin{array}{l}\text { Complexity of integrating e-learning with classroom } \\
\text { instruction }\end{array}$ & $2(6.7)$ & $11(36.7)$ & $15(50.0)$ & $1(3.3)$ & $1(3.3)$ \\
\hline Learners mastery to English language & $20(66.7)$ & $6(20.0)$ & $3(10.0)$ & - & $1(3.3)$ \\
\hline \multicolumn{6}{|l|}{ Disproportion between method and content } \\
\hline Disproportion of e-learning with curriculum content & $5(16.7)$ & $13(43.3)$ & $7(23.3)$ & $5(16.7)$ & - \\
\hline $\begin{array}{l}\text { Disproportion of e-learning courses for the } \\
\text { academic mission }\end{array}$ & $4(13.3)$ & $8(26.7)$ & $12(40.0)$ & $51(16.7)$ & $1(3.3)$ \\
\hline $\begin{array}{l}\text { Concerns about the practical nature of some courses } \\
\text { are not offered electronically }\end{array}$ & $6(20.0)$ & $7(23.3)$ & $15(50.0)$ & $11(3.3)$ & $1(3.3)$ \\
\hline \multicolumn{6}{|l|}{ A credit\& encouraging Barriers } \\
\hline Lake of research grants for e-learning & $10(33.3)$ & $13(43.3)$ & $4(13.3)$ & $31(10.0)$ & - \\
\hline Lake of Support from university & $11(36.7)$ & $12(40.0)$ & $7(23.3)$ & - & - \\
\hline Lake of support from colleagues & $4(13.3)$ & $12(40.0)$ & $9(30.0)$ & $4(13.3)$ & $1(3.3)$ \\
\hline Lack of professional credentials to teach in e-learning & $2(6.7)$ & $11(36.7)$ & $8(26.7)$ & $7(23.2)$ & $2(6.7)$ \\
\hline
\end{tabular}

Table 4 summarizes the students' attitude towards solutions for the implementation of e-learning. E-learning courses to supplement classroom teaching was a solution that mentioned by the majority of respondents 240 $(93.8 \%)$ in this study (Table 4$)$.

Table 4. Students' attitude towards solutions for the implementation of e-learning

\begin{tabular}{|c|c|c|c|c|c|}
\hline Variables & $\begin{array}{l}\text { Strongly } \\
\text { Agree } \\
\text { (\%) }\end{array}$ & $\begin{array}{l}\text { Agree } \\
(\%)\end{array}$ & $\begin{array}{l}\text { No } \\
\text { comment } \\
(\%)\end{array}$ & $\begin{array}{l}\text { Disagree } \\
\text { (\%) }\end{array}$ & $\begin{array}{l}\text { Strongly } \\
\text { Disagree } \\
(\%)\end{array}$ \\
\hline E-learning courses to supplement classroom teaching & $142(55.5)$ & $98(38.3)$ & $14(5.5)$ & - & $2(0.8)$ \\
\hline E-learning courses jointly with local universities & $116(45.3)$ & $114(44.5)$ & $23(9.0)$ & $1(0.4)$ & $2(0.8)$ \\
\hline E-learning courses jointly with foreign universities & $112(43.9)$ & $95(37.1)$ & $45(17.6)$ & $4(0.6)$ & - \\
\hline Centralized e-learning courses in the centers and units & $84(32.8)$ & $120(46.9)$ & $4(16.0)$ & $6(2.3)$ & $5(2.0)$ \\
\hline Two-way pattern (e-learning and traditional courses) & $66(25.8)$ & $95(37.1)$ & $79(30.9)$ & $10(3.9)$ & $6(2.3)$ \\
\hline Collaboration with companies in the field of e- learning & $87(34.0)$ & $103(40.2)$ & $50(19.5)$ & $14(5.5)$ & $2(0.8)$ \\
\hline A combination pattern (use some of lessons e-learning) & $72(28.1)$ & $95(37.1)$ & $59(23.0)$ & $26(10.2)$ & $4(1.6)$ \\
\hline $\begin{array}{l}\text { Optional combination pattern (to choose e-learning or } \\
\text { lesson traditional by students) }\end{array}$ & $109(42.6)$ & $85(33.2)$ & $46(18.0)$ & $13(5.1)$ & $3(1.2)$ \\
\hline E-learning courses as an independent unit and Schools & $93(36.3)$ & $98(38.3)$ & $51(19.9)$ & $11(4.3)$ & $3(1.2)$ \\
\hline E-learning courses for died serving courses & $61(23.8)$ & $69(27.0)$ & $88(34.4)$ & $32(12.5)$ & $6(2.3)$ \\
\hline E-learning courses for additional training & $45(17.6)$ & $81(31.6)$ & $81(31.6)$ & $37(14.5)$ & $12(4.7)$ \\
\hline One-way pattern (courses only in electronic form) & $47(18.4)$ & $68(26.6)$ & $77(30.1)$ & $45(17.6)$ & $19(7.4)$ \\
\hline
\end{tabular}

Table 5 summarizes Lecturers' attitude towards solutions for the implementation of e-learning. E-learning 
courses to supplement classroom teaching was a solution that mentioned by the majority of lecturers 29 (96.7\%) in this study (Table 5).

Table 5. Lecturers' attitude towards solutions for the implementation of e-learning

\begin{tabular}{|c|c|c|c|c|c|}
\hline Variables & $\begin{array}{l}\text { Strongly } \\
\text { Agree } \\
(\%)\end{array}$ & $\begin{array}{l}\text { Agree } \\
\text { (\%) }\end{array}$ & $\begin{array}{l}\text { No } \\
\text { comment } \\
(\%)\end{array}$ & Disagree & $\begin{array}{l}\text { Strongly } \\
\text { Disagree } \\
(\%)\end{array}$ \\
\hline E-learning courses to supplement classroom teaching & $18(60.0)$ & $11(36.7)$ & $1(3.3)$ & - & - \\
\hline E-learning courses jointly with local universities & $17(56.7)$ & $11(36.7)$ & $2(6.7)$ & - & - \\
\hline E-learning courses jointly with foreign universities & $15(50.0)$ & $13(43.3)$ & $1(3.3)$ & $1(3.3)$ & - \\
\hline Centralized e-learning courses in the centers and units & $11(36.7)$ & $10(33.3)$ & $8(26.7)$ & $1(3.3)$ & - \\
\hline Two-way pattern (e-learning and traditional courses) & $10(33.3)$ & $11(36.7)$ & $6(20.0)$ & $3(10.0)$ & - \\
\hline Collaboration with companies in the field of e- learning & $10(33.3)$ & $15(50.0)$ & $4(13.3)$ & $1(3.3)$ & - \\
\hline A combination pattern (use some of lessons e-learning) & $13(43.3)$ & $10(33.3)$ & $5(16.7)$ & $1(3.3)$ & $1(3.3)$ \\
\hline $\begin{array}{l}\text { Optional combination pattern (to choose e-learning or } \\
\text { lesson traditional by students) }\end{array}$ & $9(30.0)$ & $7(23.3)$ & $5(16.7)$ & $7(23.3)$ & $2(6.7)$ \\
\hline E-learning courses as an independent unit and Schools & $12(40.0)$ & $10(33.3)$ & $7(33.3)$ & $1(3.3)$ & - \\
\hline E-learning courses for died serving coursess & $8(26.7)$ & $6(20.0)$ & $7(23.3)$ & $9(30.0)$ & - \\
\hline E-learning courses for additional training & $5(16.7)$ & $4(13.3)$ & $9(30.0)$ & $12(40.0)$ & - \\
\hline One-way pattern (courses only in electronic form) & $5(16.7)$ & $3(10.0)$ & $5(16.7)$ & $10(33.3)$ & $7(23.3)$ \\
\hline
\end{tabular}

\section{Discussion}

Hormozgan province is located in south of Iran with humid and hot weather. Like other universities in developing countries Hormozgan University of Medical Sciences (HUMS) suffer from an insufficient number of members. One of the greatest benefits of e-learning is that it helps Hormozgan province to reduce the dependency on local teaching staff. Thus, through the use of e-learning the problem of staff, insufficient numbers of members can be minimized because the internet allows the design of interactive course-material which is then delivered over the network to the attending students (Clark \& Mayer, 2008).

The present study describes student dominance on English language, limited communication with the instructor and lack of proper training in e-learning courses in the university were important barrier factors to the implementation of e-learning in the HUMS according Students' perceptions. Lack of guidance and information prior to enrollment in e-learning, perceived lack of support from faculty, and difficulties in contacting them mentioned in prior studies (Brown, 1996; Pierrakeas et al., 2004; Tresman, 2002). Other researchers have found that student characteristics such as computer literacy and confidence, reading ability, and time management skills played a role in successful course completion (Miller et al., 2003; Osbon, 2001; Rovai, 2003). Student skills in their comprehension of the English language and lack of knowledge of the software are important factors in successful implementation of e-learning course.

Regarding the lecturers' perceptions in this study, the dominance of English language, lack of research grants for e-learning and lack of proper training on e-learning courses from the university were the most important barrier factors for the implementation of e-learning. These barriers mentioned in some studies. Cultural challenge in e-world learning is the issue of language, since the majority of internet content is in English language (Barron, 2000; Van Dam \& Rogers, 2002; Wilborn, 1999), Non-English speaking individuals may feel that technology has nothing to offer them since they cannot understand the content.

A study conducted by Trentin showed that teachers' awareness may be developed towards adopting a wide range of Technical Enhanced Learning (TEL) approaches (Trentin, 2006). This process enhanced the online learning environment as teachers became more knowledgeable with technology and its effects on learning outcomes. Training is an incentive for the faculty members use new technology. Faculty members who attended in-service training and workshops are more likely to use and apply new technology (Sife, 2007; Al-Alwani, 2005; Hermans 
et al., 2008). Lack of training which is related to using e-learning technology can become a major barrier factor in its implementation.

E-learning courses to supplement classroom teaching was a solution that mentioned by the majority of respondents in this study. In the prior studies some researchers had recommended pre-course orientations to help manage students' expectations and generally prepared them for distance learning (Tresman, 2002; Rovai, 2003; Ludwig \& Dunlap, 2003; Rayan, 2001; Scales, 2001; Wojciechowski, 2005). The success of any initiative with the purpose of implementing technology in an educational program depends strongly upon the attitudes of the faculty members involved (Albirini, 2004; Hamidi, 2002; Zhao et al., 2002). The overall attitude of the faculty members reflected toward computer technology directly influenced the extent of computer utilization. In order to achieve a change in teaching practices which results in a more integrated use of technology, there was a need to examine the opinions of the instructors themselves and their beliefs about innovative teaching approaches such as e-learning (Ertmer, 2005). The use of technology in learning environment more likely increases when the instructors' pedagogical approach to teaching is consistent with selected technology (Zhao et al., 2002). Positive attitude toward ICTs is widely recognized as a necessary condition for their effective implementation. Pedagogical, technical and cost issues should be taken into account for each specific technology while integrating ICTs in teaching and learning practices.

\section{Conclusion}

E-learning is evolving, whether is intended to supplement traditional face-to-face learning or be used to replace traditional learning altogether within organizations Regardless of the purpose, it is paramount that providers' designer e-learning uses to the client, and pay attention to differences in cultural learning styles and the preferences of its end users. It is important for all stakeholders of the University of Medical Sciences to know the existing ICT facilities and services and their importance in relation to their specific tasks. The positive perception of e-learning is an important result in the future education, development of the faculty of nursing, midwifery and Paramedic School. Furthermore, the development of participant's computer skills is a key issue. Research showed that human factors such as lack of computer skills, anxiety towards using computer and personal discipline are critical to the success of e-learning. Students and lecturers skills in English language and their knowledge of the software are important for the implementation of e-learning.

\section{Author's Contribution}

PL had responsibility for all aspects of this paper.

\section{Acknowledgments}

This study was funded by the Deputy of Research and Technology, Hormozgan University of Medical Sciences. Iran (Grant no. 9381). PL would like to thank all the respondents in the study for their kind participation.

\section{Conflict of Interest}

The authors declare that there is no conflict of interests regarding the publication of this paper.

\section{References}

Al-Alwani, A. E. (2005). Barriers to Integrating Information Technology in Saudi Arabia Science Education (Unpublished doctoral dissertation, University of Kansas, U.S.A.).

Albirini, A. (2004). Teachers' attitudes toward information and communication technologies: the case of Syrian EFL teachers. Journal of Computers and Education, 47(4), 373-398. http://dx.doi.org/10.1016/j.compedu.2004.10.013

Al-Zaidiyeen, N., Mei, L., \& Fook, F. (2008). In-service Teachers' Attitudes towards the Use of Information and Communication Technology in Teaching Practice: The case of Jordan. Proceeding of Paper presented at the 2nd International Malaysian Educational Technology Convention, Kuantan, Pahang Darul Makmur, Malaysia.

Barron, T. (2000). E-learning, global migration-learning circuits. Retrieved from https://books.google.com/books?isbn=1599043033.

Brown, K. (1996). The role of internal and external factors in the discontinuation of off-campus students. Distance Education, 17(1), 44-71. http://dx.doi.org/10.1080/0158791960170105

Chang, C. L. (2008). Faculty Perceptions and Utilization of a Learning Management System in Higher Education (Unpublished doctoral dissertation, Ohio University, USA).

Clark, R. C., \& Mayer, R. E. (2008). E-learning and the Science of Instruction: Proven Guidelines for 
Consumers and Designers of Multimedia Learning. San Francisco: Pfeiffer. An Imprint of Wiley.

Ertmer, P. A. (2005). Teacher pedagogical beliefs: The final frontier in our quest for technology integration?. Educational Technology Research and Development, 53(4), 25-39. http://dx.doi.org/10.1007/BF02504683

Hamdi, N. (2002). Educational uses of the Internet in Jordanian universities. Journal of Educational Science, 2, 3-34.

Hermans, R., Tondeur, J., Van Braak, J., \& Valcke, M. (2008). The impact of primary school teachers' educational beliefs on the classroom use of computers. Computers \& Education, 51(4), 1499-1509. http://dx.doi.org/10.1016/j.compedu.2008.02.001

Hernandez, R., Pardo, A., \& Delgado Kloos, C. (2007). Creating and Deploying Effective eLearning Experiences Using. LRN, IEEE Transactions on Education, 50(4). 345-351. http://dx.doi.org/10.1109/TE.2007.906895

Ludwig-Hardman, S., \& Dunlap, J. (2003). Learner Support Services for Online Students: Scaffolding for success. The International Review of Research In Open And Distributed Learning, 4(1). Retrieved from http://www.irrodl.org/index.php/irrodl/article/view/131/211

Mehralborz University, http://safa.tbzmed.ac.ir/tabid/73/Default.aspx

Miller, M. D., Rainer, R. K., \& Corley, J. K. (2003). Predictors of engagement and participation in an online course. Online Journal of Distance Learning Administration, 6(1).

Morningstar. J., \& Primlani S. (2006). Accessibility of Online Synchronous Learning Space: Challenges and Strategies, 21st Annual International Technology and Persons with Disabilities Conference, Northridge, 2006.

Osborn, V. (2001). Identifying at-risk students in videoconferencing and web-based distance education. The American Journal of Distance Education, 15(1), 41-54. http://dx.doi.org/10.1080/08923640109527073

Pierrakeas, C., Xeno, M., Panagiotakopoulos, C., \& Vergidis, D. (2004). A Comparative Study of Dropout Rates and Causes for Two Different Distance Education Courses. The International Review Of Research In Open And Distributed Learning, 5(2). Retrieved from http://www.irrodl.org/index.php/irrodl/article/view/183/804

Rovai, A. (2003). In search of higher persistence rates in distance education online programs. Internet and Higher Education, 6(1), 1-16. http://dx.doi.org/10.1016/S1096-7516(02)00158-6

Ryan, Y. (2001). The provision of learner support services online. In G. Farrell (Ed.), the changing faces of virtual education. Vancouver, Canada: The Commonwealth of Learning, 71-94.

Scalese, E. R. (2001). What can a college distance education program do to increase persistence and decrease attrition? Journal of Instruction Delivery Systems, (3), 16-20.

Sife, A., Lwoga, E., \& Sanga, C. (2007, June 13). New technologies for teaching and learning: Challenges for higher learning institutions in developing countries. International Journal of Education and Development using ICT [Online], 3(2). Retrieved from http://ijedict.dec.uwi.edu/viewarticle.php?id=246

Trentin, G. (2006). The Xanadu Project: Training Faculty in the Use of ICT for University Teaching, International Journal of Computer Assisted Learning, 22, 182-196. http://dx.doi.org/10.1111/j.1365-2729.2006.00168.x

Tresman, S. (2002). Towards a Strategy for Improved Student Retention in Programmes of Open, Distance Education: A Case Study From the Open University UK. The International Review of Research In Open And Distributed Learning, 3(1). Retrieved from http://www.irrodl.org/index.php/irrodl/article/view/75/145

Van Dam, N., \& Rogers, F. (2002). E-learning cultures around the world: Make your globalized strategy transparent. E-learning, 28-33.

Van-Braak, J. (2001). Factors influencing the use of computer mediated communication by teachers in secondary schools. Computers \& Education, 36, 41-57. http://dx.doi.org/10.1016/S0360-1315(00)00051-8

Wilborn, J. (1999). The internet: An outgroup perspective. Communication South African Journal of Research and Theory, 25(1-2), 53-57.

Wojciechowski. A., \& Palmer, L. B. (2005). Individual student characteristics: Can any be predictors of success in online classes? Online Journal of Distance Learning Administration, 8(2).

Zhao, Y., Pugh, K., Sheldon, S., \& Byers, J. (2002). Conditions for Classroom Technology Innovations. Teachers College Record, 104(3), 482-515. http://dx.doi.org/10.1111/1467-9620.00170 


\section{Copyrights}

Copyright for this article is retained by the author(s), with first publication rights granted to the journal.

This is an open-access article distributed under the terms and conditions of the Creative Commons Attribution license (http://creativecommons.org/licenses/by/3.0/). 